\title{
Customized optoelectronic in-ear sensor approaches for unobtrusive continuous monitoring of cardiorespiratory vital signs
}

\author{
Vladimir Blazek \\ Philips Chair for Medical Information Technology, Helmholtz-Institute for Biomedical Engineering, RWTH Aachen \\ University, Aachen, Germany, blazek@hia.rwth-aachen.de \\ The Czech Institute of Informatics, Robotics and Cybernetics (CIIRC), Czech Technical University in Prague, \\ Prague, Czech Republic \\ Boudewijn Venema \\ Philips Chair for Medical Information Technology, Helmholtz-Institute for Biomedical Engineering, RWTH Aachen \\ University, Aachen, Germany, venema@hia.rwth-aachen.de \\ Steffen Leonhardt \\ Philips Chair for Medical Information Technology, Helmholtz-Institute for Biomedical Engineering, RWTH Aachen \\ University, Aachen, Germany, leonhardt@hia.rwth-aachen.de \\ Paul Blazek \\ cyLEDGE Media, Vienna, Austria, p.blazek@cyledge.com
}

Received (17.10.2018.); Revised (21.11.2018.); Accepted (06.12.2018.)

\begin{abstract}
Customization of diagnostic and therapeutic pathways in medicine and personalization of medical devices are currently major trends in biomedical engineering together with miniaturization, digitalization and increasingly ambient and unobtrusive sensor strategies. This article presents a novel optoelectronic sensor: its concept is based on simple, easy-to-use classical photoplethysmography technology, but is attached to the ear. Via the ear channel or the inner tragus, the sensor detects diagnostically relevant parameters from peripheral arterial and venous blood volume movement (including heart rate, heart rate variability, respiratory activity, blood oxygen saturation and other subdermal blood phenomena). The diagnostic system consists of customizable i) sensor forms, ii) biodata mining, and iii) communication protocols sent to the medical control center. This article describes novel possibilities for cardiorespiratory monitoring with these sensors characterized by enhanced customization features. In contrast to established art sensor applications on fingers or toes, this optical in-ear sensor technology offers additional physiological and technological advantages by mining vital signs in the ear channel. Since the optical in-ear sensor is comfortable, noninvasive and unobtrusive, it is recommended not only for patients at high cardiovascular risk but also (potentially) for homecare application and the monitoring of physical activities, e.g. during high altitude climbing. Preliminary results demonstrate that vital signs can be assessed with sufficient robustness and accuracy and that, due to the customized sensor application, patient comfort is higher compared with the classical wearable (non-customized) sensors.
\end{abstract}

Key words: Customized medical sensors, patient usability, personalized medical devices, unobtrusive long-term monitoring, vital signs

\section{INTRODUCTION}

In Western countries the number of people requiring medical care, as well as long-term and high-risk patients, is steadily increasing. This is mainly due to an aging society and the increasing prevalence of certain diseases (e.g. diabetes, obesity, arteriosclerosis, hypertension), many of which are due to an unhealthy lifestyle. The resulting burden on healthcare systems has thrust health issues into the social arena, emphasizing the need for more research and interventions to deal with the issues of both prevention and cure. This raises questions concerning: i) how to reduce the number of persons dependent on long-term medical care, and ii) how to make treatment more cost-effective.

Since personalization of medicine might contribute to overcoming these challenges, it has received increasing attention. One example is investigating the potential for more precise diagnostic and more person-specific treatment based on latest gene technology. Other possibilities emerging from the innovative technologies for mass customization and from 'intelligent' products have received less attention. Nevertheless, to support most of these new developments, appropriate sensors are generally required.

The aim of the present study is to contribute to the investigation of personalized medicine with mass 
customization research by focusing on medical sensor technology. More specifically the idea that is brought further regards the use of bodily signals to dynamically tailor a sensor and to use additional technology to personalize a specific sensor to measure specific physiological signals. In demonstrating that this is feasible with a specific kind of sensor, the present study suggests that this approach can also be used for other sensors, prostheses and/or wearable medical devices.

In the past, the efforts devoted to advance the evidencebased medicine brought to impressive advancements. The demonstrations that a certain principle or technique is effective in a population lead to rule out ideas not or negative effective on a population. However, nowadays we have new and new possibilities that are making increasingly feasible and therefore considered and applied an individually-based medicine. The rules of an 'average-based strategy' are no longer enough, it has to take into account the individuality of each person [1-5]. Since medical issues are not common in mass customization literature, and measurement of physiological signals is not common knowledge, the next section (Section 2) provides a brief background to these topics. Subsequently, Section 3 presents the specific innovation proposed in the present article and the results of the tests performed to assess the effectiveness of this innovation. Section 3 also discusses the obtained results in relation to current technological developments and their implications for mass customization. Finally, the Conclusion section considers some general issues and makes some recommendations for future research.

\section{THEORETICAL BACKGROUND}

\subsection{Customization in healthcare and biomedical engineering}

During the last decade, an increasing number of wellproven industrial mass customization activities have been adapted to the medical and paramedical fields. The individualized or personalized medicine (PM) has become a buzz word in the academic as well as public debate surrounding health care [6]. Recently, the OM concept has been clearly defined [6] and the economic evaluation of personalized medicine has been investigated [7]. Table 1 reports an overview of the methodological issues in the economic evaluation of personalized medicine [7].

In 2013, personalized medicine activities mainly focused on economic healthcare aspects: "The concept of personalized medicine is generally used to describe interventions which seek to improve stratification and timing of healthcare by utilizing biological information and biomarkers on the level of molecular disease pathways...in addition to clinical patient characteristics" $[6,7]$.

In 2015, the first activities in personalized healthcare technology, with a focus on pharmacogenomics [8], appeared and later (in March 2018) a definition of personalized medical devices was published by the International Medical Device Regulations Forum [9]: "Personalized medical device: a generic term to describe any of the types of devices that are intended for a particular individual, which could be either a custommade, or adaptable, or patient-specific medical device".

Table 1. An overview of economic evaluation of personalized medicine [7].

\begin{tabular}{|c|c|c|}
\hline \multirow{7}{*}{ 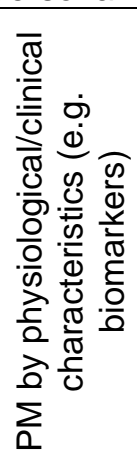 } & \multirow{2}{*}{$\begin{array}{l}\text { Impact on } \\
\text { model structure }\end{array}$} & Complex care pathways \\
\hline & & Spill over effects \\
\hline & \multirow{3}{*}{$\begin{array}{l}\text { Data } \\
\text { requirement }\end{array}$} & $\begin{array}{l}\text { Heterogeneity of } \\
\text { baseline risks and } \\
\text { treatment effect }\end{array}$ \\
\hline & & $\begin{array}{l}\text { Impact of test threshold } \\
\text { on cost-effectiveness }\end{array}$ \\
\hline & & Evidence gaps \\
\hline & \multirow[b]{2}{*}{$\begin{array}{l}\text { Analysis of } \\
\text { uncertainty }\end{array}$} & Value further research \\
\hline & & $\begin{array}{l}\text { Appropriate time } \\
\text { horizons }\end{array}$ \\
\hline \multirow{7}{*}{ 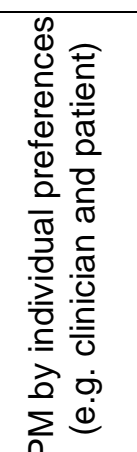 } & \multirow{2}{*}{$\begin{array}{l}\text { Evaluative } \\
\text { framework }\end{array}$} & Welfarist viewpoint \\
\hline & & ffarist viewpoint \\
\hline & \multirow{3}{*}{$\begin{array}{l}\text { Stated } \\
\text { preferences }\end{array}$} & Risk attitude \\
\hline & & Risk perception \\
\hline & & $\begin{array}{l}\text { Incorporating preference } \\
\text { heterogeneity }\end{array}$ \\
\hline & \multirow{2}{*}{$\begin{array}{l}\text { Revealed } \\
\text { preferences }\end{array}$} & $\begin{array}{l}\text { Uptake of test and } \\
\text { intervention }\end{array}$ \\
\hline & & $\begin{array}{l}\text { Impact of } \\
\text { personalization on } \\
\text { adherence }\end{array}$ \\
\hline
\end{tabular}

\subsection{Basics of photoplethysmographic physiological measurements}

Photoplethysmography (PPG) is a well-established, simple-in-use and low-cost optical technique with novel possibilities that allow to detect blood volume changes in the dermal micro- and microvascular bed. Due to their non-invasive nature, these sensors now play a key role in functional blood circulation diagnosis. They are generally well accepted by patients during, for example, a vascular screening examination since they cause no pain, and do not involve harmful radiation or ionizing phenomena. Moreover, in the near future, they will be able to operate remotely, implying that they will be totally unobtrusive.

Following the pioneering work of Cartwright [10], Haxthausen [11], Matthes [12] and Molitor et al. [13], Alrick B. Hertzman (physiologist at St. Louis University School of Medicine, USA), discovered in 1938 a relationship between the intensity of backscattered polychromatic light and blood volume in the skin. His instruments consisted of three essential components still found in modern systems: a light source, a light detector (Fig. 1, left) and a registration unit. He called the device a 'photoelectric plethysmograph' and published his findings ([14], p. 336):

- "volume pulse of the skin as an indicator of the state of the skin circulation at rest", and,

- "amplitude of volume pulse as a measure of the blood supply of the skin". 

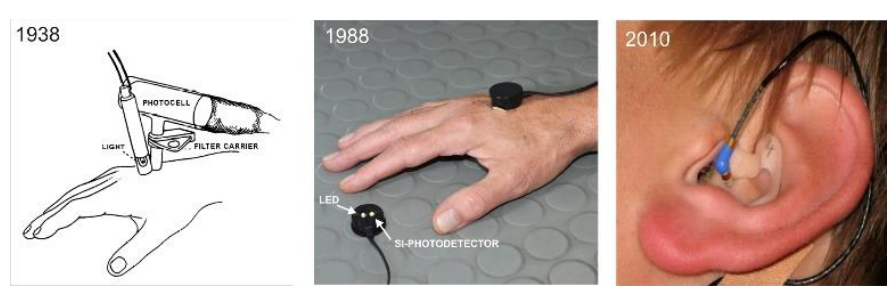

Figure 1. Progress in photoplethysmography and its sensor concepts. Left, first optoelectronic sensor by Hertzman [14] with incandescent lamp as polychromatic light source and selenium cell as photo detector; Middle, universal reflective PPG sensor currently available; Right, novel personalized reflective in-ear PPG sensor.

The basic principle behind the measurement of blood volume changes in the skin by means of PPG is the simple fact that hemoglobin in the blood absorbs infrared light many times more strongly than the remaining skin tissue [6-10]. For example, as blood pressure in the skin vessels decreases, the surface area of the vessels is reduced. This increases the average reflection in the measuring window under the sensor, so it will be recorded as an increase in the PPG signal. Following this principle, the PPG signal reflects blood volume changes in the cutaneous and (partially) also the subcutaneous vessel plexus, and consists of a high constant part which is independent from the perfusion (light scattering in tissue), a smaller quasi-static vein signal, and a very small, periodical modulated arterial signal (Fig. 2). Therefore, this non-invasive technique allows to acquire functional data from dermal venous and/or arterial hemodynamics. Separation of the venous and arterial perfusion components of the detected photoplethysmogram is possible by selective postprocessing of the signal.

\subsection{Implications of customized medical sensors from the perspective of engineering sciences using reflexive photoplethysmography as an example}

A promising approach for possible cost reductions in curative long-term care, is to shift the therapeutic processes to a home environment to avoid costly hospital stays. Sensor systems that continuously record vital signs and integrate them, as unobtrusively as possible, into everyday life offer new perspectives to optimize and develop treatment methods and improve the quality of life of at-risk patients and individuals in need of care. An important task of medical-related engineering is the development of everyday sensor systems for hemodynamic health monitoring, which can be used on a mobile basis.

A promising technological basis is the non-invasive and cost-effective PPG datamining process, which allows the development of systems for continuous long-term use. The first devices for unobtrusive measurement of vital processes based on reflexive PPG are already commercially available (e.g. a fitness wristband). They are the forerunners of a trend in medical technology that envisages the integration of personalized vital signs in all areas of life. Until now, these systems measure only elementary vital functions (such as heart rate) which far from exhausts the metrological and diagnostic potential

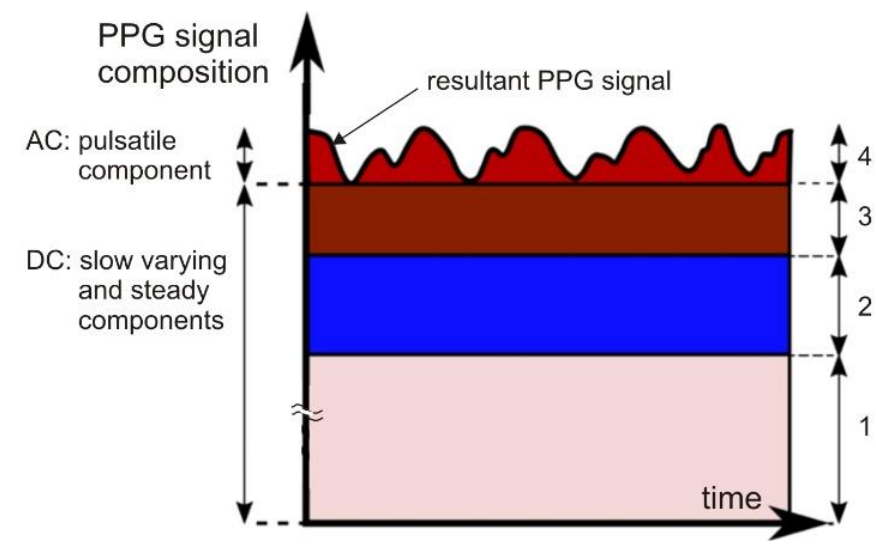

Figure 2. Typical composition of the photoplethysmographic signal in the ear channel. 1: Static signal part due to measuring light interaction with bloodless tissue compartments; 2: Signal part due to measuring light interaction with venous blood volume compartments; 3: Signal part due to measuring light interaction with the average arterial blood volume within the sample; and 4: The pulsatile arterial blood volume compartments. Reducing blood volume in the transilluminated area under the PPG sensor increases the PPG signal.

of PPG. In addition to the heart rate, latest smart PPG devices provide information on heart rate variability, respiratory activity, or hematological parameters such as the concentration of oxygen, hemoglobin or dysfunctional hemoglobin in the blood. The possibility of obtaining metrological insight into the autonomic nervous system via heart rate variability or vasodilation is of particular societal interest, since this leads to quantification of physical wellbeing. Such a measurement of physical stress can be valuable for a wide range of clinical scenarios, and also represents a measurable variable in a performance-based society in everyday life. Since the routine use of sensors is in its early stages, various challenges and opportunities inevitably arise. Whereas engineering sciences are faced with the considerable challenges of adapting a clinical measuring method for everyday use, medicine will be able to design new forms of therapy and optimize treatment processes. Based on these sensor technologies that will be integrated into everyday life, information can be continuously collected to quantify the physiological processes in an individualized way [5].

\section{DEVELOPMENT AND TEST OF HIGLHLY CUSTOMIZED IN-EAR PPG SENSORS}

Since 2010, different types of ear sensor module prototypes have been developed and clinically tested at the RWTH Aachen University. For example, for one in-ear module, the optoelectronic chip is sealed into a biocompatible ear mold, which is individually customized to the patient's ear (e.g. for long-term usage: intensive care or home care). This sensor ensures the highest level of wearing comfort, optimal fit, and best reproducibility with regard to the sensor's position. Other types of sensors were also developed; these were made from elastic material and in five different sizes to ensure adaptation to 
any individual's ear structure and, therefore, to fit almost everyone (e.g. for short-term usage).

The reflective PPG in-ear sensor design was previously developed in the INMONIT, LAVIMO and smart PPG research projects funded by the German Federal Ministry of Education and Research, and the German Federal Ministry of Economic Affairs and Energy. Figure 3 shows some steps in the development and construction of various PPG ear sensors.

Compared to conventional PPG devices attached to a finger or ear lobe, our novel in-ear PPG strategy offers major advantages. Firstly, due to its proximity to the brain, the inner ear canal is expected to be less affected by centralization; this ensures better performance in lifethreatening situations such as shock, hypothermia or sepsis. Furthermore, an in-ear sensor is convenient to wear and less frequently disrupted by motion artifacts and, therefore, suitable for long-term monitoring and even for homecare application.

\subsection{Collection of vital data and design of monitoring system}

With the aging society, national health systems will have to cope with the challenge of an expanding elderly population who are increasingly vulnerable for diseases. Encouraging individuals to accept a more active role in prevention, therapy and rehabilitation by means of personalized training and relaxation exercises will not only help to optimize treatment and prolong individual lives, but will also reduce public healthcare costs.
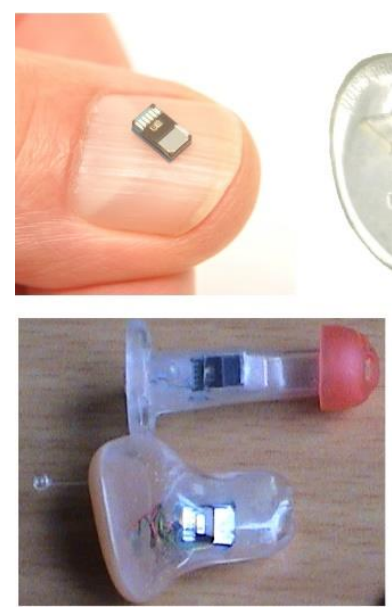
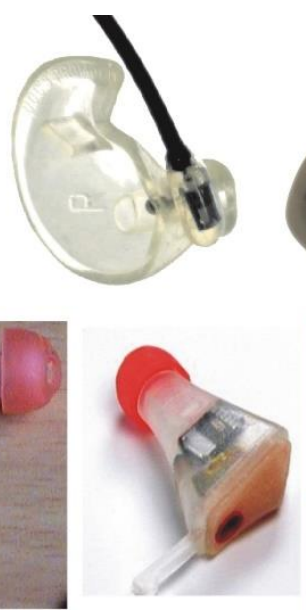
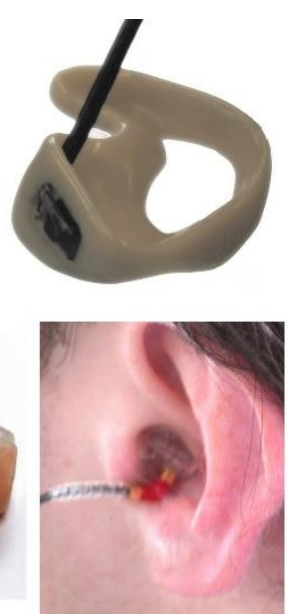

Figure 3. Different in-ear PPG sensor prototypes developed at the RWTH Aachen University. Above left, silicon chip containing the light emitters and the photo-receiver (CiS Erfurt, Germany); Above middle, universal in-ear sensor module (available in different sizes); Above right, individually customized sensor module. Lower panel, different patientspecific sensor prototypes, which can be placed directly into the ear channel.

Portable 24/7 monitoring systems and non-invasive sensor concepts may play an important role by allowing continuous monitoring of vital bodily functions and generating data to improve the individual's health situation and offer support in a crisis. A prerequisite for a mobile unobtrusive monitoring system was the development of a remission PPG sensor element to be placed in the outer ear channel; this measurement modality does not disturb the user during daily activities. It can also be assumed that, due to the proximity to the brain, more robust measurements are available during critical hemodynamic situations, since the head (unlike the fingers or toes) is not affected by centralization issues. From this point of view, the ear channel can be seen as a monitoring keyhole to the heart.

To analyze the potential of this measuring approach, several customizable types of sensor-interface devices have been developed in our laboratory, i.e. Bluetooth enhanced sensor-PC interfaces, USB-based sensor-PC interfaces, and stand-alone devices (Fig. 4) with several firmware-related energy-saving strategies. One of the most difficult aspects in low-power wireless sensor applications is the continuous wireless transmission of vital data with the required power consumption. In the developed interface electronic, we implemented the Bluetooth (BT) 4.0 communication standard using a BLE112-A Bluetooth module including low-energy profile. This offers the most energy effective, standardized wireless transmission for Smartphone applications available today. Although the BLE112-A consists of a programmable microcontroller, due to the complexity of the digital signal processing, an additional MSP430F169 (Texas Instruments, ultra-low mixed signal processor) microcontroller as main processing unit is used. Additional technical details are available in [20-26].

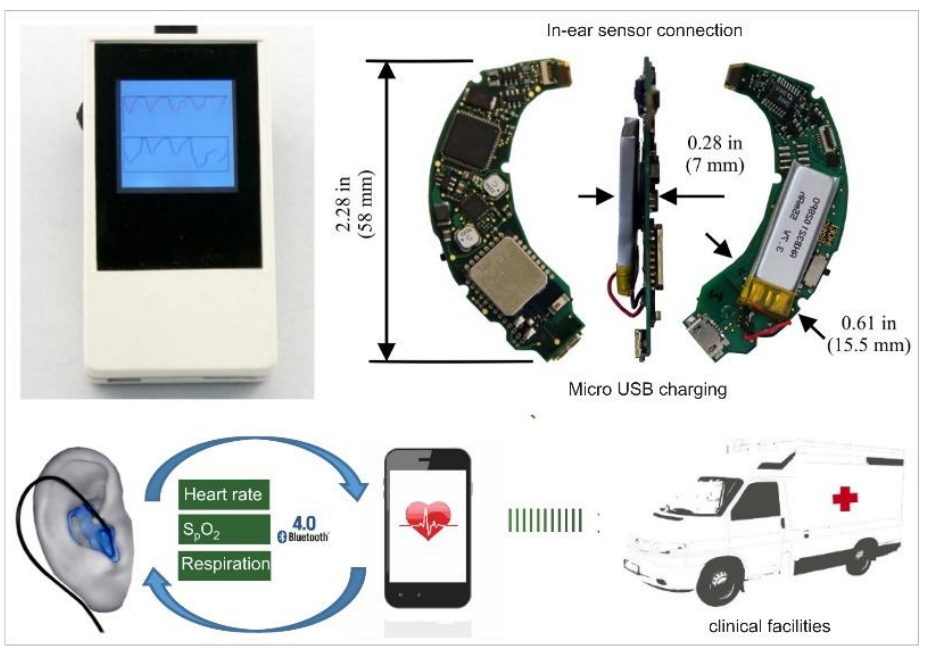

Figure 4. Upper panel, the in-ear PPG monitoring system strategy as (left) a single stand-alone device, or (right) a highly integrated behind-ear unit; Lower panel, as a part of a medical support monitoring chain.

\subsection{Advanced adaptable algorithm strategies}

Typical PPG signal recordings assessed in the ear channel are presented in Fig. 5. From these data, basic heart and respiratory activity parameters can be derived. In addition, analysis of autonomous rhythmical phenomena in the dermal perfusion, or analysis of stress/pain can be performed using advanced algorithm strategies in the time or frequency domain.

In order to differentiate between, e.g., relaxation and stress, analysis of the heart rate and respiratory rate is required, since stress is generally associated with an increase in both these parameters. However, since stress is a physiological phenomenon with very high 
inter- and intra-individual variation, an 'absolute' quantification of a stress level remains a challenge.

Analysis of the highly individual set of generated health data shows that customized data analysis strategies are required.

Latest research focuses on variations in respiration and heart frequency, since this is more promising and effective for quantification of stress level. Also, pain is a subjective feeling that is influenced by various endogenous and external factors. Generally speaking, pain assessment can also be seen as stress assessment. Due to the anesthetic procedure during a surgical intervention, external influences are reduced. The currently used algorithms for pain assessment, e.g. the Analgesia Nociception Index [27] or the Surgical Stress Index [28], analyze heart rate, pulse amplitude, and heart rate variability based on ECG or PPG recordings [29]. In our experience, the waveform of the peripheral arterial blood volume pulse, analyzed using the Oliva-Roztocil algorithm, is a promising new way to quantify pain [30-32].

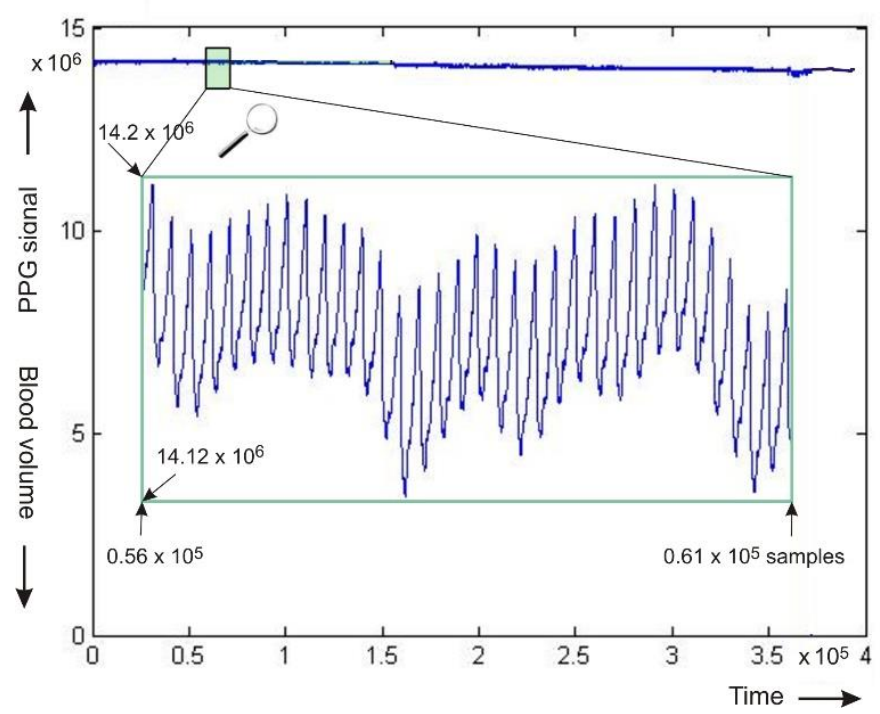

Figure 5. Typical photoplethysmogram detected in the ear. In this case, the DC signal amplitude is approximately $14.15 \times 10^{6}$, and the AC signal $0.5 \times 10^{4}$.

The extraction of vital parameters from the PPG signals can be done both in the time domain and frequency domain. In theory, this is easy to implement because the subdermal blood volume fluctuations and, thus, light modulation is directly coupled to the physiological process.

In practice, this very general algorithmic approach is suboptimal in most practical situations, due to interference from, e.g. motion artifacts, ambient light fluctuations, temperature effects, and other external disruptors that corrupt the signal. Last but not least, the clinical scenario affects the plethysmogram in various ways. To minimize this metrological, physiological and pathophysiological uncertainty, algorithms have been developed that extract vital signs in different ways. The fusion of these extracted parameters increases the robustness of the diagnostically relevant information.

Our group is constantly working on algorithms that are based on this principle and address various parameters.
Moreover, these algorithms have been validated in patients in clinical centers [22, 23].

Due to its complexity, we provide a brief description of the adaptive method based on the evaluation of respiratory activity.

Breathing modulates the PPG signal in various ways that can be redundantly evaluated:

- $\quad$ time/frequency domain analysis [33],

- heartbeat variability analysis (respiratory sinus arrhythmia) [34, 35],

- temporal variation of blood oxygen saturation $[22,36]$.

The signal derivatives are independently separated from the signals by algorithms and automatically evaluated [37]. Depending on the individual patient and the clinical indication (e.g. diabetes, peripheral vascular disease) and situation (stress, exercise, wellness, etc.) these algorithms deliver signal derivatives of varying robustness. Only the redundant evaluation approach can provide the required robustness of the resulting vital parameter, which meets the precision requirements of personalized diagnostics. Self-learning algorithmic fusion is one of the greatest challenges in developing self-deciding algorithms with regard to the functional safety of a medical device, and is the main focus of our research activities.

\subsection{Individualized PPG sensor testing}

In five human trials we demonstrated the clinical relevance of the in-ear monitoring system.

First, human hypoxia studies were performed in 2011 in collaboration with the University Hospital of Schleswig Holstein in Lübeck (Prof. Gehring) including 20 participants in order to calibrate the system. In addition, the system was tested under realistic clinical conditions with patients undergoing surgery in 2011/2012; these trials (43 patients) were also performed at the University Hospital of Schleswig Holstein. In a third study, our system was evaluated for sleep diagnostics. This study took place at the University Hospital Aachen in collaboration with Prof. Schiefer. The study included 20 patients who probably suffered from obstructive sleep apnea.

Preliminary results indicated excellent nocturnal performance of the system, which might (in part) be due to darkness and reduced motion scenario. Nevertheless, motion artifacts can always disrupt the signal, especially face-related motions like chewing, coughing, etc. Although studies indicate that walking up to $5 \mathrm{~km} / \mathrm{h}$ does not significantly affect signal quality, it would be useful to further investigate this topic (i.e. accelerometer-assisted PPG, piezo/ultrasound enhanced contact pressure measurement, intelligent artifact algorithm). The fourth study tested our system and the feasibility of continuous health monitoring during high altitude mountaineering at about $3000 \mathrm{~m}$ in 10 healthy subjects; the results of this study were promising.

Finally, the wearing comfort of both sensor concepts was evaluated; 10 volunteers rated the wearing comfort of a personalized sensor and a universal in-ear sensor after $45 \mathrm{~min}$ on a scale from 0 (imperceptible) to 10 (unbearable). The average score for the custom-made 
sensor was 0.75 and that for the universal sensor was 1.8. The personalized sensors also proved better in the comparative assessment of the average signal quality of both sensor types; the normalized root mean square error for the personalized sensors was $0.11 \%(-44.04$ $\mathrm{dB})$ compared with $0.13 \%(-42,30 \mathrm{~dB})$ for the universal sensors [36].

\section{CONCLUSIONS}

We have presented a custom-made and easy-to-use medical PPG device system for in-ear detection of multiple diagnostically relevant cardiorespiratory vital signs. The system includes a customized in-ear sensor and various miniaturized electronic device modalities for digitalization, signal analysis, human interface and longterm data storage. Due to the proximity to the brain, a stable measurement performance is expected not only for patients at cardiovascular risk, but also as a control and surveillance alarming system for physiologic distress among, e.g., pilots, firemen, drivers and professional athletes, like high altitude climbers [38].

Our current in-ear PPG measurement and data acquisition system offers the following possibilities:

- intelligent front-end sensor concept (using a miniaturized PPG device, without any controls, executable and manageable via the associated software),

- long-term perfusion studies (also 24/7),

- multi-channel and multi-wavelength design,

- full signal recording (recording of the complete PPG signal without signal distortion by the filter in the chain),

- 200 measurement values per channel and per second,

- 24-bit digitalization precision,

- future-proof PC connection via USB,

- $\quad$ powered by the USB bus (no battery needed),

- data saving in data files, allowing reloading for advanced algorithmic studies.

In the further development of such sensors, all three dimensions of customization (fit, functionality, and form [39]) are relevant when developing a sensor's features, together with the sensor's data services that will support the personalized health approaches.

The further development of such sensors will open new application possibility. These sensors can be part of wider systems that provide new functionalities and new services to persons. The development of new services based on these sensors and the evaluation of the operative and economic implications of their use are open field for new research.

\section{ACKNOWLEDGMENTS}

The authors are grateful for generous financial support from the German Federal Ministry for Economic Affairs and Energy, and from the German Federal Ministry of Education and Research. The authors also thank the following companies: CiS (Erfurt) for providing sensor hardware, ELCAT (Wolfratshausen) for successful cooperation in the development/completion of the entire
PPG system design, and PromoTool (Berlin) for powerful and timely project management. Last but not least, the first author thanks his former PhD students for supporting this project and the related feasibility studies.

\section{REFERENCES}

[1] Ng, P.C., Murray, S.S., Levy, S. and Venter, J.C. (2009), "An agenda for personalized medicine", Nature, Vol. 461, No. 8, pp. 724-726.

[2] Egnew, T.R., (2009), "Suffering, Meaning, and Healing: Challenges of Contemporary Medicine", Annals of Family Medicine, Vol. 7, No. 2, pp. 170-175.

[3] Hamburg, M.A. and Collins, F.S. (2010), "The path of personalized medicine”, New England Journal of Medicine, Vol. 363, No. 4, pp. 301-304.

[4] Swan, M. (2012), "Health 2050: The realization of personalized medicine through crowdsourcing, the quantified self, and the participatory biocitizen", Journal of personalized medicine, Vol. 2, No. 3, pp. 93-118.

[5] Schork, N.J. (2015), "Personalized medicine: Time for oneperson trials", Nature, Vol. 520, No. 7549, pp. 609-611.

[6] Schleidgen, S., Klingler, C., Bertram, T., Rogowski, W.H. and Marckmann, G. (2013), "What is personalized medicine: sharpening a vague term based on systematic literature review", BMC Med. Ethics, Vol. 14, No. 55, pp. 55-66.

[7] Rogowski, W., Payne, K., Schnell-Inderst, P., Manca, A., Rochau, U., Jahn, B., Alagoz, O., Leidl, R. and Siebert, U. (2015), "Concepts of 'personalization' in personalized medicine: implications for economic evaluation", Pharmacoeconomics, Vol. 33, No. 1, pp. 49-59.

[8] www.nih.gov

[9] www.imdrf.org/documents/documents.asp

[10] Cartwright, C.M. (1930), "Infrared transmission of the flesh", Journal of the Optical Society of America, Vol. 20, No. 2, pp. 81-84.

[11] Haxthausen, H. (1933), "Infra-red photography of subcutaneous veins", British Journal of Dermatology, Vol. 45, pp. 506-511.

[12] Matthes, K. (1935), "Untersuchungen über die Sauerstoffsättigung des menschlichen Arterienblutes", NaunynSchmiedebergs Archiv für experimentelle Pathologie und Pharmakologie, Vol. 179, No. 6, pp. 698-711.

[13] Molitor, H. and Kniazuk, M. (1936), "A new bloodless method for continuous recording of peripheral circulatory changes", Journal of Pharmacology and Experimental Therapeutics, Vol. 57, No. 1, pp. 6-18.

[14] Hertzman, A.B. (1938), "The blood supply of various skin areas as estimated by the photoelectric plethysmograph", American Journal of Physiology-Legacy Content, Vol. 124, No. 2, pp. 329-340.

[15] Barnes, R.W. (1991), "Noninvasive diagnostic assessment of peripheral vascular disease", Circulation, Vol. 83, No. 2, pp. 120-127.

[16] Blazek, V. and Schultz-Ehrenburg, U. (1996), "Quantitative Photoplethysmography. Basic facts and examination tests for evaluating peripheral vascular functions", VDI Verlag Düsseldorf, Germany.

[17] Belcaro, G., Incandela, L., Veller, R., Nicolaides, A.N., et al. (1998), "Noninvasive investigations in vascular disease", Angiology, Vol. 49, No. 9, pp. 673-706.

[18] Schultz-Ehrenburg, U. and Blazek, V. (2001), "Value of Quantitative Photoplethysmography for Functional Vascular Diagnostics. Current Status and Prospects", Skin Pharmacology and Physiology, Vol. 14, No. 5, pp. 316-324.

[19] Allen, J. (2007), "Photoplethysmography and its application in clinical physiological measurement", Physiological measurement, Vol. 28, No. 3, R1-R39.

[20] Hülsbusch, M., Blazek, V., Herzog, M., Vogel, S., Wartzek, T., Starke, D. and Hennig, T. (2009), "Development of a miniaturized in-ear pulse oximeter for long-term monitoring of risk patients". In: Dössel, O., Schlegel, W.C. (Eds): WC 2009, IFMBE Proceedings 25/IV, Springer Verlag 2009, pp. 779-781.

[21] Vogel, S., Hülsbusch, M., Hennig, T. Blazek, V. and Leonhardt, S. (2009), "In-ear vital signs monitoring using a novel microoptic reflective sensor", IEEE Transactions on Information Technology in Biomedicine, Vol. 13, No. 6, pp. 882-889

[22] Venema, B., Gehring, H., Michelsen, I., Blanik, N., Blazek, V. and Leonhardt, S. (2013), "Robustness, Specificity and Reliability of an In-ear Pulse Oximetric Sensor in Surgical Patients", IEEE 
Journal of Biomedical and Health Informatics, Vol. 18, No. 4, pp. 1178-1185.

[23] Venema, B., Schiefer, J., Blazek, V., Blanik, N. and Leonhardt S. (2013), "Evaluating Innovative In-ear Pulse Oximetry for Unobstructive Cardiovascular Homecare Monitoring during Sleep", IEEE Journal of Translational Engineering in Health and Medicine, Vol. 1, 8 pages.

[24] Venema, B., Wolke, M., Blazek, V. and Leonhardt, S. (2014), "A Power Consumption Optimized Reflective In-ear Pulse Oximeter for Mobile Health Monitoring", Biomedical Wireless Technologies, Networks, and Sensing Systems (BioWireleSS), 2014 IEEE Topical Conference, pp. 34-36.

[25] Venema, B., Blanik, N., Perlitz, V., Laffar, S., Ortlepp, H.G., Borik, S., Jansen, J.-P., Koeny, M., Blazek, V. and Leonhardt, S. (2014), "Biofeedback - Smart Modality Fusion for Clinical, Home and Outdoor Health Monitoring", Biomedical EngineeringBiomedizinische Technik, Vol. 59, pp. S132-S135.

[26] Venema, B., Blazek, V. and Leonhardt, S. (2015), "In-Ear Photoplethysmography for Mobile Cardiorespiratory Monitoring and Alarming", Proceeding of the 2015 IEEE 12th International Conference on Wearable and Implantable Body Sensor Networks, 5 pages.

[27] Logier, R., Jeanne, M., Dassonneville, A., Delecroix, M. and Tavernier, B. (2010), "PhysioDoloris: a monitoring device for analgesia/nociception balance evaluation using heart rate variability analysis", Engineering in Medicine and Biology Society (EMBC), 2010 Annual International Conference of the IEEE, pp. 1194-1197.

[28] Struys, M.M.R.F., Vanpeteghem, C., Huiku, M., Uutela, K., Blyaert, N.B.K. and Mortier, E.P. (2007), "Changes in a surgical stress index in response to standardized pain stimuli during propofol-remifentanil infusion", British Journal of Anaesthesia, Vol. 99, No. 3, pp. 359-367.

[29] Köny, M., Yu, X. and Czaplik, M. (2013), "Computing the Analgesia Nociception Index Based in PPG Signal Analysis", Proceedings 17th International Student Conference on Electrical Engineering, Prague.
[30] Korpas, D., Halek, J. and Dolezal, L. (2009), "Parameters describing the pulse wave”, Physiological research, Vol. 58, No. 4, pp. 473-479.

[31] Oliva, I. and Roztocil, K. (1983), "Pulse wave analysis in obliterating atherosclerosis", Angiology, Vol. 34, No. 9, pp. 610-619.

[32] Blazek, V., Blanik, N., Blazek, C.R., Paul, M., Pereira, C.B., Koeny, M., Venema, B. and Leonhardt, S. (2017), "Active and Passive Optical Imaging Modality for Unobtrusive Cardiorespiratory Monitoring and Facial Expressions Assessment", Anesthesia \& Analgesia, Vol. 124, No. 1, pp. 104-119.

[33] Blazek, V. (2010), "New Insights in the Phenomenon of Distributed Dermal Perfusion Rhythmicity using Computer Aided Optoelectronic Sensor Measuring Strategies", Acta Mechanica Slovaca, Vol. 14, No. 2, pp. 42-50.

[34] Angelone, A. and Coulter, N.A. (1964), "Respiratory sinus arrhythmia: a frequency dependent phenomenon", Journal of Applied Physiology, Vol. 19, No. 3, pp. 479-482.

[35] Hirsch, J.A. and Bishop, B. (1981), "Respiratory sinus arrhythmia in humans: how breathing pattern modulates heart rate", American Journal of Physiology-Heart and Circulatory Physiology, Vol. 241, No. 4, pp. 620-629.

[36] Walton Z.D., Kyriacou P.A., Silverman D. and Shelley K.H. (2010) "Measuring venous oxygenation using the photoplethysmo-graph waveform", Journal of Clinical Monitoring and Computing, Vol. 24, No. 4, pp. 295-303.

[37] Venema, B. (2015), „Photonische Sensorkonzepte für ein mobiles Gesundheitsmonitoring", PhD Thesis, RWTH Aachen University, Shaker Verlag Aachen

[38] Venema, B. and Leonhardt, S. (2017), "In-ear Pulse Oximetry in High Altitude Mountaineering", Proceedings on the $13^{\text {th }}$ IASTED International Conference on Biomedical Engineering (BioMed), pp. 254-259.

[39] Piller, F. and Blazek, P. (2014), "Core Capabilities of Sustainable Mass Customization". In: Felfernig, A., Hotz, L., Bagley, C., Tiihonen, J. (eds.): Knowledge-based Configuration: From Research to Business Cases, Morgan Kaufmann-Elsevier, Waltham, pp. 107-120.

\title{
Kastomizovani optoelektronski senzori u uhu za nenametljivo kontinualno praćenje kardiorespiratornih vitalnih znakova
}

\author{
Vladimir Blazek, Boudewijn Venema, Steffen Leonhardt, Paul Blazek
}

Primljen (17.10.2018.); Recenziran (21.11.2018.); Prihvaćen (06.12.2018.)

\begin{abstract}
Apstrakt
Kastomizacija dijagnostičkih i terapeutskih sredstava u medicini i personalizacija medicinskih uređaja trenutno su glavni trendovi u biomedicinskom inženjerstvu zajedno sa minijaturizacijom, digitalizacijom i sve ambijentalnijim $i$ nenametljivim senzorskim strategijama. U radu je predstavljen novi optoelektronski senzor, pričvršćen za uho čiji koncept se zasniva na jednostavnoj i lakoj za upotrebu klasičnoj tehnologiji fotopletizmografije. Preko ušnog kanala ili unutrašnjeg tragusa, senzor detektuje dijagnostički relevantne parametre iz kretanja volumena periferne arterije $i$ venske krvi (uključujući broj otkucaja srca, varijabilnost srčanog ritma, respiratornu aktivnost, saturaciju kiseonika u krvi i druge subdermalne krvne parametre). Dijagnostički sistem se sastoji od kastomizabilnih i) senzorskih formi, ii) prikupljanja bio-podataka, i iii) komunikacionih protokola slanja podataka medicinskom kontrolnom centru. Ovaj rad opisuje nove mogućnosti za praćenje kardiorespiratornih funkcija uz pomoć senzora koje karakterišu poboljšane mogućnosti kastomizovanja. Za razliku od senzora koji se postavljaju na prste ruku ili nogu, ova optička senzorska tehnologija nudi dodatne fiziološke i tehnološke prednosti praćenja vitalnih znakova u kanalu uha. Budući da je optički senzor u uhu udoban, neinvazivan i nenametljiv, preporučuje se ne samo za pacijente sa visokim kardiovaskularnim rizikom, već i (potencijalno) za kućnu negu pacijenata ili praćenje fizičkih aktivnosti, npr. penjanja na velikoj nadmorskoj visini. Preliminarni rezultati pokazuju da se vitalni znaci mogu proceniti dovoljno robusno i precizno i da je, zahvaljujući kastomizovanoj primeni senzora, udobnost za pacijenta veća u poređenju sa klasičnim nosivim (nekastomizovanim) senzorima.
\end{abstract}

Ključne reči: Kastomizovani medicinski senzori, upotrebljivost za pacijenate, personalizovani medicinski uređaji, nenametljiv dugoročni nadzor, vitalni znaci 